\title{
Energy-Efficient and Environmentally Friendly Solid Oxide Membrane Electrolysis Process for Magnesium Oxide Reduction: Experiment and Modeling
}

\begin{abstract}
XIAOFEI GUAN, UDAY B. PAL, and ADAM C. POWELL
This paper reports a solid oxide membrane (SOM) electrolysis experiment using an $\operatorname{LSM}\left(\mathrm{La}_{0.8} \mathrm{Sr}_{0.2} \mathrm{MnO}_{3-\delta}\right)$-Inconel inert anode current collector for production of magnesium and oxygen directly from magnesium oxide at $1423 \mathrm{~K}\left(1150{ }^{\circ} \mathrm{C}\right)$. The electrochemical performance of the SOM cell was evaluated by means of various electrochemical techniques including electrochemical impedance spectroscopy, potentiodynamic scan, and electrolysis. Electronic transference numbers of the flux were measured to assess the magnesium dissolution in the flux during SOM electrolysis. The effects of magnesium solubility in the flux on the current efficiency and the SOM stability during electrolysis are discussed. An inverse correlation between the electronic transference number of the flux and the current efficiency of the SOM electrolysis was observed. Based on the experimental results, a new equivalent circuit of the SOM electrolysis process is presented. A general electrochemical polarization model of SOM process for magnesium and oxygen gas production is developed, and the maximum allowable applied potential to avoid zirconia dissociation is calculated as well. The modeling results suggest that a high electronic resistance of the flux and a relatively low electronic resistance of SOM are required to achieve membrane stability, high current efficiency, and high production rates of magnesium and oxygen.
\end{abstract}

DOI: $10.1007 / \mathrm{s} 40553-014-0013-\mathrm{x}$

(C) The Minerals, Metals \& Materials Society and ASM International 2014

\section{INTRODUCTION}

SOLID oxide membrane (SOM) electrolysis is an electrolytic metal extraction technique that is low in energy and capital costs, and also environmentally friendly. It requires minimum preprocessing, the plant is scalable, and has a smaller footprint. The process directly reduces oxides or oxide compounds to their respective metals, alloys, or intermetallics, such as magnesium $(\mathrm{Mg})$, tantalum $(\mathrm{Ta})$, titanium $(\mathrm{Ti})$, calcium $(\mathrm{Ca})$, ytterbium $(\mathrm{Yb})$, silicon $(\mathrm{Si})$, Ti-Fe alloy, Ti-Si intermetallics, etc. ${ }^{[1-17]}$

Because of its simplicity and efficiency, the SOM process is the lowest-cost method proposed for producing $\mathrm{Mg}$ with cost estimated at $\$ 1.36 / \mathrm{kg}$, much lower than that for $\mathrm{MgCl}_{2}$ electrolysis, siliconthermic reduction (the Pidgeon process), and the carbothermic reduction. ${ }^{[7]}$ The SOM process for $\mathrm{Mg}$ production employs an oxygen-ion-conducting yttria-stabilized zirconia (YSZ) membrane to separate a liquid metal anode from a molten fluoride flux containing magnesium oxide $(\mathrm{MgO})$. During electrolysis, magnesium cations are

XIAOFEI GUAN, Postdoctoral Research Associate, and UDAY B. PAL, Professor, are with the Department of Mechanical Engineering and the Division of Materials Science and Engineering, Boston University, Boston, MA. Contact e-mail: upal@bu.edu ADAM C. POWELL, Chief Technology Officer, is with Infinium Inc., Natick, MA.

Manuscript submitted January 30, 2014.

Article published online April 15, 2014 reduced at the cathode, while oxygen anions are transported through the YSZ membrane to the anode where they are oxidized. It has been reported that a novel LSM $\left(\mathrm{La}_{0.8} \mathrm{Sr}_{0.2} \mathrm{MnO}_{3-\delta}\right)$-Inconel inert anodic current collector and liquid silver anode are successfully used in SOM electrolysis experiments for $\mathrm{O}_{2}$ evolution. ${ }^{[6]}$ The YSZ membrane selectively conducts oxygen ions but blocks other elements such as fluorine. In addition, the YSZ membrane prevents $\mathrm{O}_{2}$ from backreaction with the reduced $\mathrm{Mg}$. Therefore, the pure $\mathrm{O}_{2}$ evolved can be easily collected and also sold to offset some of the capital cost and further lower the Mg price point.

Previous work has shown that $\mathrm{Mg}$ has a finite solubility in the fluoride flux used in SOM electrolysis. ${ }^{[4,6,18,19]}$ The dissolution of $\mathrm{Mg}$ imparts electronic conductivity to the flux, which negatively affects the SOM electrolysis in two ways: First, the electronic conductivity of the flux decreases the SOM electrolysis current efficiency. SOM electrolysis has been shown to have high current efficiencies (approximately 90 pct) at the beginning for short time periods. ${ }^{[2,18]}$ However, as the electrolysis continues, the current efficiency drops significantly to 40 through 50 pct due to electronic current in the flux caused by the dissolved Mg. ${ }^{[4,18]}$ Second, the electronic conductivity in the flux provides a pathway for the applied potential to reduce the zirconia $\left(\mathrm{ZrO}_{2}\right)$ at the outer surface of the YSZ membrane. ${ }^{[20]}$ YSZ membrane is known to be stable in $\mathrm{MgF}_{2}-\mathrm{CaF}_{2}$ flux containing a small concentration of $\mathrm{YF}_{3}$, when no electric potential is applied across the membrane. ${ }^{[21]}$ 
However, when the flux has some electronic conductivity, it is possible for the flux to essentially act as an extended cathode. In this case, the applied potential reduces the $\mathrm{ZrO}_{2}$ at the surface of the YSZ membrane. Gratz et al..$^{[20]}$ have observed the YSZ membrane degradation due to the electrochemical dissociation of $\mathrm{ZrO}_{2}$ during SOM electrolysis.

Regarding the important role of $\mathrm{Mg}$ solubility, it is important to monitor and evaluate $\mathrm{Mg}$ dissolution in the flux during electrolysis. In this work, electronic transference numbers of the flux $\left(t_{\mathrm{e}, \text { flux }}\right)$ between two steel electrodes are measured to assess the $\mathrm{Mg}$ dissolution in the flux during electrolysis. The correlation between $t_{\mathrm{e} \text {,flux }}$ and the current efficiency of the SOM electrolysis is discussed. Based on the electrochemical characterizations, a new equivalent circuit is presented to model the SOM electrolysis process. In addition, a polarization model of SOM process for $\mathrm{Mg}$ and $\mathrm{O}_{2}$ production is developed, and the maximum allowable applied potential to avoid $\mathrm{ZrO}_{2}$ dissociation is calculated. Modeling of the SOM electrolysis process provides insights for increasing both the current efficiency and the YSZ membrane stability.

\section{EXPERIMENTAL}

\section{A. SOM Electrolysis Setup}

Figure 1 shows the schematic of a SOM electrolysis setup. It consisted of an upper reaction chamber heated to $1423 \mathrm{~K}\left(1150{ }^{\circ} \mathrm{C}\right)$ and a lower condensing chamber having a temperature gradient of $1373 \mathrm{~K}$ to $473 \mathrm{~K}\left(1100{ }^{\circ} \mathrm{C}\right.$ to $\left.200^{\circ} \mathrm{C}\right)$. The setup was fabricated using grade 304 stainless steel (SS-304) and heated in industrial grade $\mathrm{Ar}$ (Airgas). Inside the reaction chamber, $470 \mathrm{~g}$ of powdered flux (45 wt pet $\mathrm{MgF}_{2}-55$ wt pet $\mathrm{CaF}_{2}$ containing $5 \mathrm{wt}$ pet $\mathrm{MgO}$ and $2 \mathrm{wt}$ pct $\mathrm{YF}_{3}$ ) was used to form the molten electrolyte; $45 \mathrm{wt}$ pct $\mathrm{MgF}_{2}-55$ wt pct $\mathrm{CaF}_{2}$ is a eutectic composition having a melting temperature of $1247 \mathrm{~K}\left(974{ }^{\circ} \mathrm{C}\right)^{[22]}$; YF3 was added to prevent yttrium depletion from the YSZ membrane. ${ }^{21]}$ A one-end-closed $6 \mathrm{~mol}$ pct YSZ tube (McDanel Advanced Ceramics) separated the flux from $44 \mathrm{~g}$ of liquid silver encased inside the YSZ tube. An LSM-Inconel inert anode current collector was disposed in the YSZ tube and was submerged in the liquid silver anode. ${ }^{[23]}$ An SS-304 bubbling tube served as the cathode. Alumina spacers were used to electrically isolate the YSZ membrane and the bubbling tube from the reaction chamber.

During the experiment, forming gas (95 pct Ar-5 pct $\mathrm{H}_{2}$ ) was used to purge the reaction chamber. The gas flowing rate through the bubbling tube was $180 \mathrm{~cm}^{3} / \mathrm{min}$, and the flow rate through the annulus between the bubbling tube and the SS-304 tube extending out of the top of the reaction chamber was $300 \mathrm{~cm}^{3} / \mathrm{min}$. There was no gas flow through the annulus between the YSZ membrane and its outside SS-304 tube. The forming gas lowered the partial pressure of $\mathrm{Mg}$ vapor over the flux and carried the $\mathrm{Mg}$ vapor into the condenser (see
Figure 1). The $\mathrm{Mg}$ vapor in the condenser was cooled and condensed on a steel shim placed along the inner walls of the chamber. The bubbling gas also stirred the flux to facilitate the transport of $\mathrm{Mg}$ vapor out of the flux and achieve chemical homogeneity in the flux.

\section{Electrochemical characterization of SOM electrolysis cell}

The electrochemical characterization of the SOM electrolysis cell was performed between the LSM-Inconel inert anode current collector and the bubbling tube cathode. Electrochemical impedance spectroscopy (EIS) scans were performed to measure the ohmic resistance of the SOM electrolysis cell. The EIS scans were performed using a Princeton Applied Research 263A potentiostat and a Solartron 1250 frequency response analyzer. These impedance scans were from 20,000 to $1 \mathrm{~Hz}$ with $20 \mathrm{mV}$ amplitude. The ohmic resistance of the measured cell was obtained from the value of the high-frequency intercept on the real axis of the Nyquist plot. ${ }^{[24,25]}$

When an applied potential exceeded the dissociation potential of $\mathrm{MgO}, \mathrm{Mg}$ vapor was produced at the bubbling tube cathode, and $\mathrm{O}_{2}$ evolved at the liquid silver anode. The overall cell reaction is given as

$$
\mathrm{MgO}=\mathrm{Mg}(\mathrm{g})+\frac{1}{2} \mathrm{O}_{2}(\mathrm{~g})
$$

Potentiodynamic scans at $5 \mathrm{mV} / \mathrm{s}$ were performed to determine the dissociation potential of $\mathrm{MgO}$. Electrolysis runs were performed by applying a constant electric potential greater than the dissociation potential of $\mathrm{MgO}$. The potentiodynamic scans and the electrolysis runs were performed using an Agilent Technologies N5743A power source. $\mathrm{O}_{2}$ gas evolution was observed at the anode once the liquid silver anode became saturated with $\mathrm{O}_{2}$. The anode exit gas passed through a FMA4305 digital flow meter (OMEGA Engineering) that measured the flow rate of the evolved $\mathrm{O}_{2}$.

\section{Measurement of the electronic transference number of the flux}

Periodically, the electrolysis was halted, and the electronic transference number of the flux between the reaction chamber and the bubbling tube was measured to assess the $\mathrm{Mg}$ dissolution in the flux. The electronic and ionic resistances of the flux can be modeled by two resistors in parallel. Therefore, the relationship between the total ohmic resistance $\left(R_{\mathrm{T}(\mathrm{flux})}\right)$, the ohmic electronic resistance $\left(R_{\mathrm{e}(\mathrm{flux})}\right)$, and the ohmic ionic resistance $\left(R_{\mathrm{i}(f l u x)}\right)$ of the flux between the reaction chamber anode and the bubbling tube cathode can be expressed by

$$
\frac{1}{R_{\mathrm{T}(\mathrm{flux})}}=\frac{1}{R_{\mathrm{e}(\mathrm{flux})}}+\frac{1}{R_{\mathrm{i} \text { (flux })}}
$$

EIS scan was performed between the reaction chamber and the bubbling tube to determine $R_{\mathrm{T}(\text { flux })}$, and it was equal to the value of the high-frequency intercept on the real axis of the Nyquist plot. The ohmic electronic resistance, $R_{\text {e(flux) }}$, was determined by performing a 


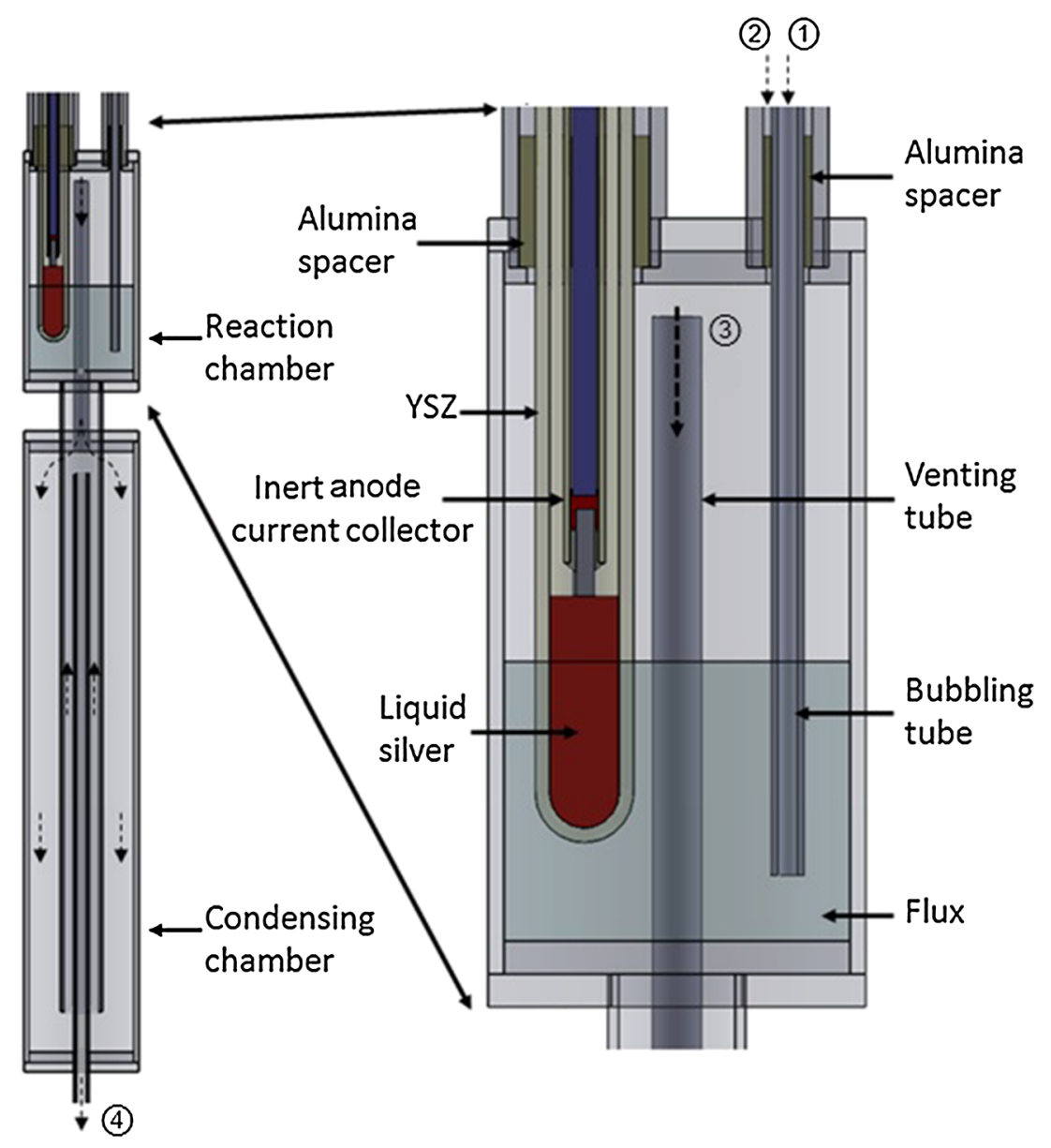

Fig. 1-Schematic of the cross section of a SOM electrolysis setup. The components of the setup are indicated by the solid arrows. The dashed arrows show the flow of forming gas: 1 forming gas flowing through the bubbling tube into the reaction chamber, 2 forming gas flowing through the annulus between the bubbling tube and its outside SS-304 tube, 3 forming gas and $\mathrm{Mg}$ vapor mixture flowing through the venting tube leading to the condensing chamber, and 4 forming gas flowing out.

potentiostatic hold between the two electrodes using a Princeton Applied Research 263A potentiostat. In each potentiostatic hold, a constant electric potential $(\sim 0.1 \mathrm{~V})$ is applied, and the current response was measured. The ohmic electronic resistance, $R_{\text {e(flux) }}$, was obtained by dividing the applied potential by the measured current. It should be noted that the anodic terminal was switched from the liquid silver to the reaction chamber for the above EIS and the potentiostatic holds.

According to Eq. [2], $R_{\mathrm{i}(\mathrm{flux})}$ was calculated from the measured values of $R_{\mathrm{T}(\text { flux })}$ and $R_{\mathrm{e}(\mathrm{flux})}$. Based on the knowledge of $R_{\mathrm{e} \text { (flux) }}$ and $R_{\mathrm{i} \text { (flux) }}, t_{\mathrm{e} \text { (flux) }}$ was calculated using the following equation ${ }^{[26]}$ :

$$
t_{\mathrm{e}(\mathrm{flux})}=\frac{R_{\mathrm{i}(\mathrm{flux})}}{R_{\mathrm{e}(\mathrm{flux})}+R_{\mathrm{i}(\mathrm{flux})}}
$$

\section{Microstructural characterization}

After the SOM electrolysis experiment, the setup was disassembled for detailed analysis and characterization. A piece of the YSZ membrane was mounted in epoxy, polished, coated with gold, and then examined using a JSM-6100 JEOL scanning electron microscope (SEM).

\section{RESULTS}

\section{A. Ohmic Resistance of the SOM Cell}

At the beginning of the experiment, an EIS scan was performed between the inert anode current collector and the bubbling tube, and the results are shown in Figure 2. The high-frequency intercept on the Nyquist plot corresponds to the cell ohmic resistance, which includes the resistances of the YSZ membrane, the flux, the electrodes, the external lead wires, and the contact resistances associated with all the interfaces. The cell ohmic resistance was measured to be $0.54 \Omega$, close to earlier reported SOM electrolysis cell resistance obtained with LSM-Inconel current collector. ${ }^{[6]}$

\section{B. Current-Potential Characteristics of the SOM Cell}

A PDS was conducted between the inert anode current collector and the bubbling tube after the EIS, and the current-potential relationship is shown in Figure 3. The dissociation potentials of the impurity oxides (such as $\mathrm{Fe}_{2} \mathrm{O}_{3}$ dissolved into the flux from the crucible walls) and $\mathrm{MgO}$ were identified to be approximately $1.3 \mathrm{~V}$ and $2.17 \mathrm{~V}$, respectively. The leakage 


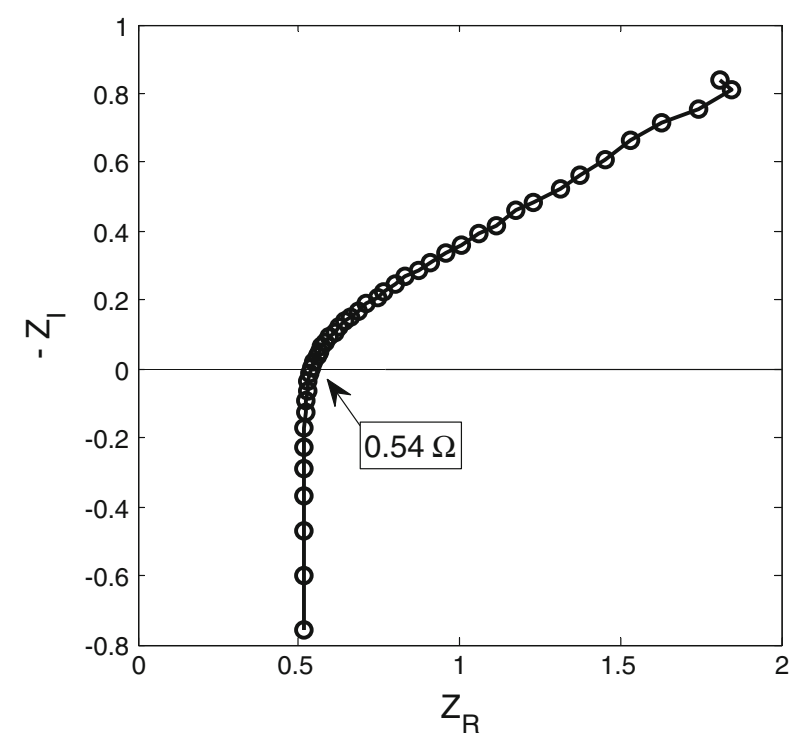

Fig. 2-Electrochemical impedance spectroscopy (EIS) results at the beginning of the SOM electrolysis experiment at $1423 \mathrm{~K}\left(1150^{\circ} \mathrm{C}\right)$. The ohmic resistance of the SOM cell was $0.54 \Omega$.

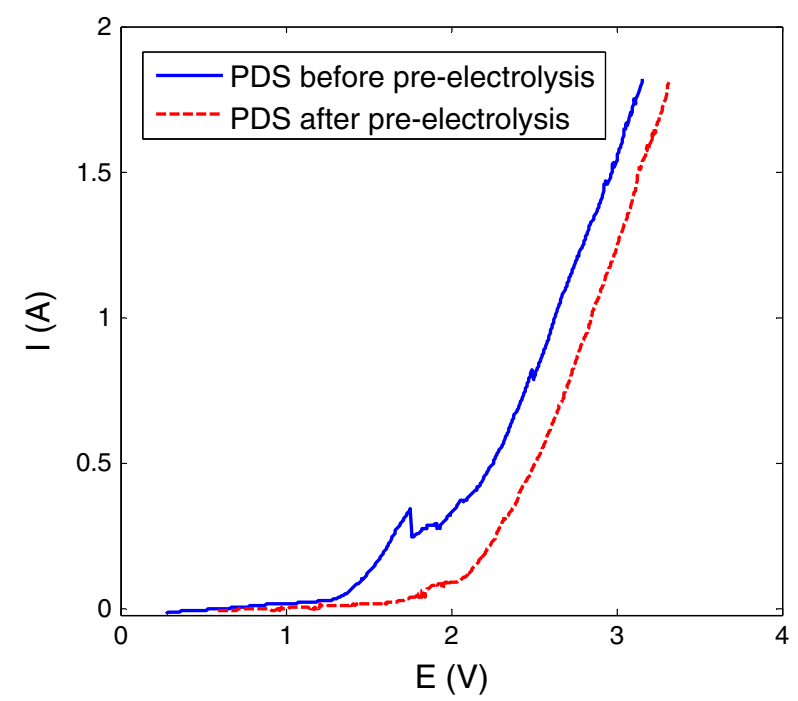

Fig. 3-Potentiodynamic scans $(5 \mathrm{mV} / \mathrm{s})$ showing the current-potential relationships before pre-electrolysis (solid line) and after pre-electrolysis (dashed line).

current caused by the dissociation of impurity oxides is approximately $0.4 \mathrm{~A}$. To reduce the leakage current, a pre-electrolysis at an electric potential slightly less than $2.17 \mathrm{~V}$ was performed to dissociate the impurity oxides. The starting current was measured to be $0.484 \mathrm{~A}$. After 70 minutes of pre-electrolysis, the measured current dropped to a negligibly small value $(0.022 \mathrm{~A})$, and then the pre-electrolysis was stopped. The total charge passed during pre-electrolysis was $289 \mathrm{C}$.

After the pre-electrolysis, another PDS was conducted between the LSM-Inconel inert anode current collector and the bubbling tube, and the current-potential relationship is also shown in Figure 3. The leakage current caused by impurity oxides was significantly reduced by the pre-electrolysis. The negligible leakage current also indicates that there was no electronic current since no $\mathrm{Mg}$ was generated and dissolved in the flux during preelectrolysis. The electric potential for $\mathrm{MgO}$ dissociation was identified to be approximately $2.08 \mathrm{~V}$. At this point of time, the impurity oxides had been removed, and there was no dissolution of $\mathrm{Mg}$ in the flux yet.

\section{SOM Electrolysis Runs}

Afterward, electrolysis was performed thrice, each for 6 hours, between 2.3 and $2.6 \mathrm{~V}$, to dissociate $\mathrm{MgO}$ (see Figure 4). During electrolysis, the $\mathrm{O}_{2}$ gas produced at the anode passed through a digital flow meter that measured the $\mathrm{O}_{2}$ evolution rate. The current efficiency is calculated by dividing the faradaic current for $\mathrm{O}_{2}$ production by the total current passing through the cell. The calculated current efficiency is shown in Figure 5. The steady-state current efficiency decreased as more $\mathrm{Mg}$ was produced during SOM electrolysis.

\section{Electronic Transference Number of the Flux}

Before the first electrolysis, and immediately after each electrolysis, $t_{\mathrm{e}(\mathrm{flux})}$ between the bubbling tube and the reaction chamber were measured. The dependence of $t_{\mathrm{e}(f l u x)}$ as a function of time is shown in Figure 5, and the values are listed in Table I. It is shown in Figure 5 that initially $t_{\mathrm{e}(f l u x)}$ was low and the current efficiency was high, but with continued electrolysis the efficiency decreased and $t_{\mathrm{e}(f l u x)}$ increased until the flux reached the solubility limit for $\mathrm{Mg}$ dissolution. This indicates an inverse correlation between the current efficiency of the SOM electrolysis and the electronic conductivity of the flux.

\section{E. Post-Experimental Analysis}

After the SOM electrolysis experiment, the furnace was cooled, and the setup was disassembled. Figure 6 shows the $\mathrm{Mg}$ collected on the stainless steel shim lining the inner walls of the condenser. Figure 7 shows the SEM images of a piece of the YSZ membrane sample. The outer layer of the YSZ membrane contacting the flux showed high porosity. This indicates that the YSZ membrane's degradation took place during the electrolysis. This result is consistent with what has been observed in previous work. ${ }^{[20]}$

\section{MODELING}

\section{A. Equivalent Circuit Modeling}

Equivalent circuit is a very useful tool to model the $\mathrm{SOM}$ electrolysis process for producing $\mathrm{Mg}$ and $\mathrm{O}_{2}$. Based on the experimental results, it is now understood that the impurity oxides (such as $\mathrm{Fe}_{2} \mathrm{O}_{3}$ ) in the flux contribute to the leakage current. It is also known that the dissolved $\mathrm{Mg}$ in the flux imparts electronic conductivity to the flux. The electronic conductivity in the flux reduces the current efficiency of the SOM electrolysis and provides a pathway for the applied potential to 
dissociate $\mathrm{ZrO}_{2}$ in the YSZ membrane. A new equivalent circuit of the SOM electrolysis process is presented as shown in Figure 8. The symbols used in Figure 8 are defined in Table II. This equivalent circuit is more comprehensive than those presented by Krishnan et al. ${ }^{[2]}$ and Gratz et al., ${ }^{[20]}$ because it takes into account (1) the

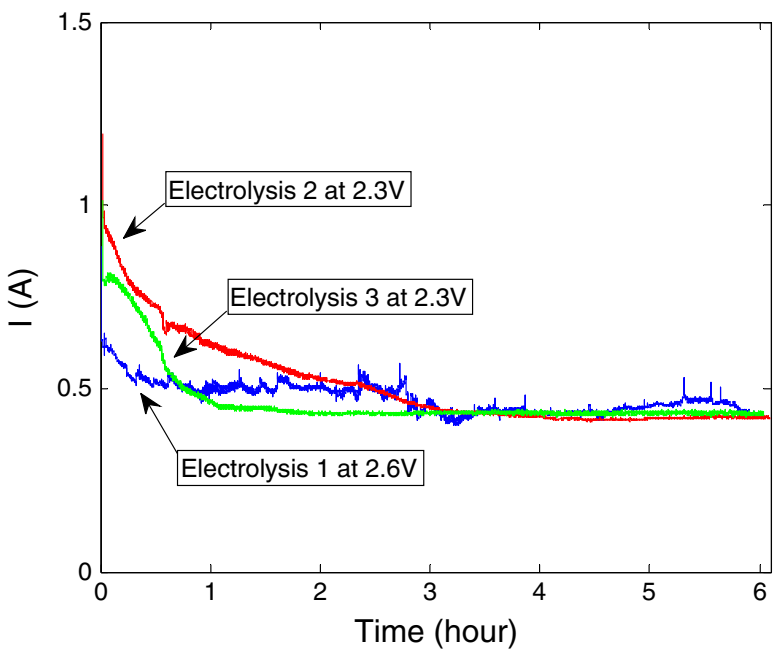

Fig. 4-The current-time plots during the three electrolyses at $1423 \mathrm{~K}\left(1150^{\circ} \mathrm{C}\right)$ with applied potentials between 2.3 and $2.6 \mathrm{~V}$. dissociation of $\mathrm{Fe}_{2} \mathrm{O}_{3}$ dissolved in the flux, (2) the electronic conductivity of the flux caused by dissolved $\mathrm{Mg}$, and (3) the dissociation of $\mathrm{ZrO}_{2}$ in the $\mathrm{YSZ}$ membrane.

The equivalent circuit first shows that impurity oxides, such as $\mathrm{Fe}_{2} \mathrm{O}_{3}$, with greater cation electronegativity than $\mathrm{Mg}$ will dissociate before $\mathrm{MgO}$. A preelectrolysis is usually conducted to remove the $\mathrm{Fe}_{2} \mathrm{O}_{3}$.

After the pre-electrolysis, an electric potential exceeding the dissociation potential of $\mathrm{MgO}$ is applied. Once the $\mathrm{MgO}$ dissociates, $\mathrm{Mg}$ is produced at the cathode. Some of the $\mathrm{Mg}$ produced dissolves in the flux, and the rest evolves as vapor and is carried away by the forming gas or argon. The dissolved $\mathrm{Mg}$ subsequently increases the electronic conductivity of the flux. The YSZ membrane has electronic conductivity at the operating temperature $\left[1423 \mathrm{~K}\left(1150^{\circ} \mathrm{C}\right)\right]$ and the other prevailing experimental conditions. ${ }^{[27]}$ A flux with electronic conductivity essentially serves as an extended cathode, and it allows electronic current to pass through the flux and the membrane, decreasing the current efficiency. If the flux had no electronic conductivity, then the current passing through the flux would be purely ionic, and the entire energy input to the cell would be used in the process of dissociating $\mathrm{MgO}$. The presence of an electronic current acts as an internal short circuit in the SOM process.

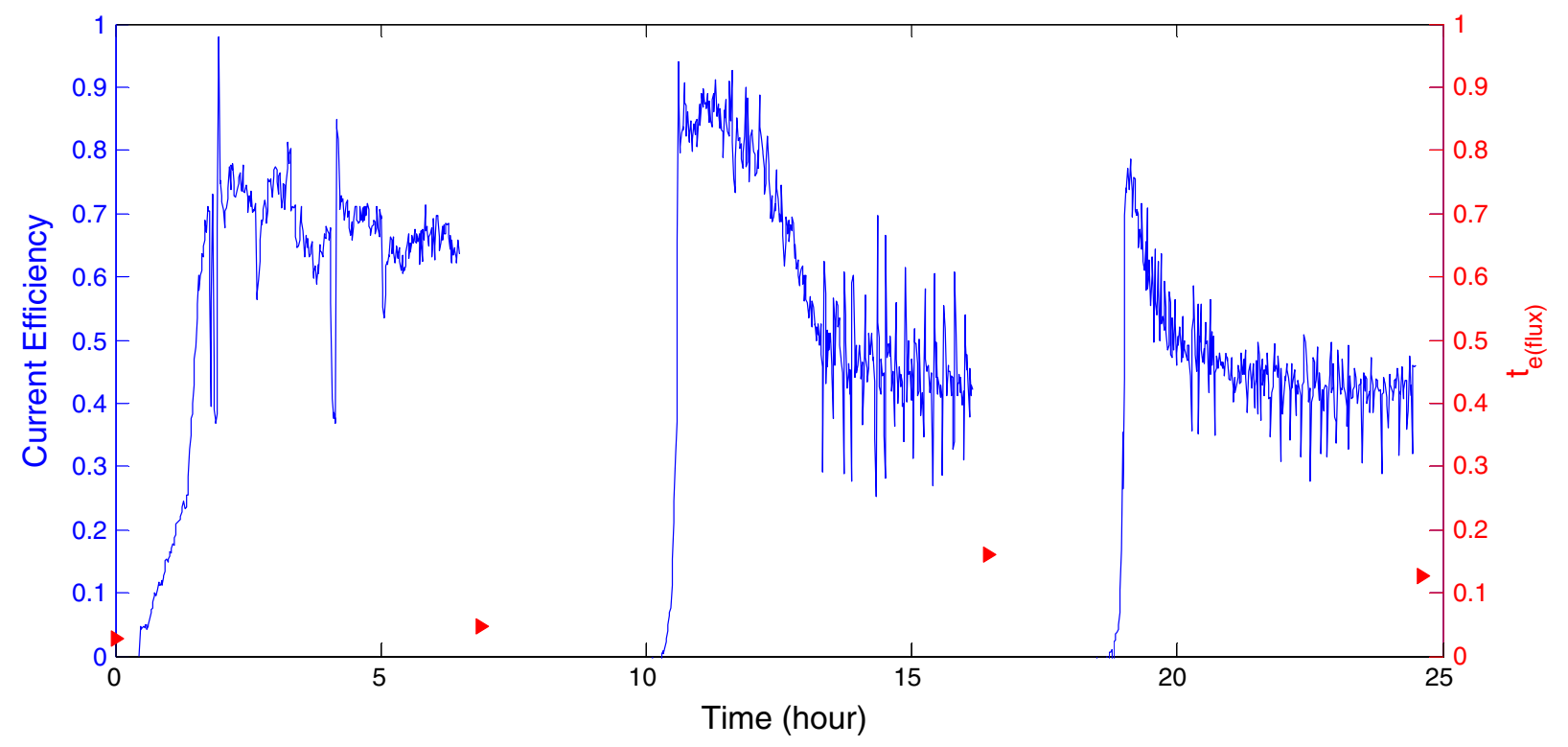

Fig. 5-The decrease in the current efficiency (solid line) during electrolysis as the Mg dissolves in the flux and the electronic transference number (red triangle) increases. The asymptotic behavior indicates that the flux reaches the solubility limit for Mg dissolution (Color figure online).

Table I. The Measured Resistances $\left(R_{\mathrm{T}(\mathrm{flux})}, \boldsymbol{R}_{\mathrm{e}(\text { flux })}\right.$, and $\left.\boldsymbol{R}_{\mathrm{i}(\text { flux })}\right)$ and the Electronic Transference Number ( $\left.t_{\mathrm{e}(\text { flux })}\right)$ of the Flux Between the Reaction Chamber and the Bubbling Tube

\begin{tabular}{lcccc}
\hline Measurement & $R_{\mathrm{T}(\text { flux })}(\Omega)$ & $R_{\mathrm{e}(\text { flux })}(\Omega)$ & $R_{\mathrm{i}(\text { flux }}(\Omega)$ & $t_{\mathrm{eflux}}$ \\
\hline 1st & 0.160 & 5.857 & 0.164 & 0.027 \\
2nd & 0.150 & 3.110 & 0.158 & 0.048 \\
3rd & 0.168 & 1.048 & 0.200 & 0.160 \\
4th & 0.126 & 1.001 & 0.144 \\
\hline
\end{tabular}




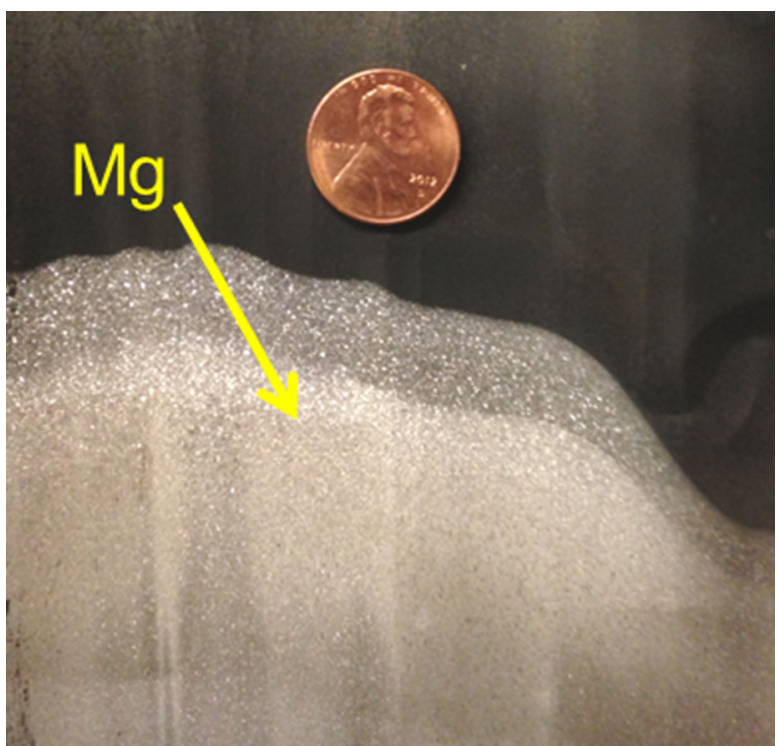

Fig. 6- Mg collected on the stainless steel shim lining the inner walls of the condenser shown in scale with a US one-cent coin.

As more $\mathrm{Mg}$ dissolves into the flux, the electronic conductivity of the flux will further increase. The increased electronic conductivity also decreases the electronic potential drop across the flux, and then the potential drop across the YSZ membrane must correspondingly increase, while a constant DC electric potential is applied across the entire cell. The increased potential drop across the YSZ can cause the dissociation of $\mathrm{ZrO}_{2}$, which will degrade the YSZ membrane. To avoid $\mathrm{ZrO}_{2}$ dissociation, the potential drop across the YSZ membrane should not exceed the dissociation potential of $\mathrm{ZrO}_{2}$.

\section{B. Polarization Model for $\mathrm{Mg}$ and $\mathrm{O}_{2}$ production}

After the $\mathrm{Fe}_{2} \mathrm{O}_{3}$ is removed and before any $\mathrm{Mg}$ is dissolved in the flux, the electronic resistance of the flux is very high; therefore it is reasonable to assume that the entire current is used for dissociating $\mathrm{MgO}$ during electrolysis. In this case, only the circuit branch for $\mathrm{MgO}$ dissociation needs to be considered, and the remaining branches can be ignored (see the equivalent circuit in Figure 8. The applied potential $\left(E_{\text {applied }}\right)$ can be expressed as follows:

$$
\begin{aligned}
E_{\text {applied }}= & \left|E_{\mathrm{N}}^{\mathrm{MgO}}\right|+\eta_{\mathrm{ohm}}+\eta_{\text {act }}+\eta_{\text {conc }, \mathrm{c}} \\
& +\eta_{\text {conc }, \mathrm{a}}+\eta_{\text {over,anode } / \mathrm{YSZ}},
\end{aligned}
$$

where $\left|E_{\mathrm{N}}^{\mathrm{MgO}}\right|$ is the absolute value of the Nernst potential for $\mathrm{MgO}$ dissociation, $\eta_{\mathrm{ohm}}$ is the ohmic polarization of the SOM electrolysis cell, $\eta_{\text {act }}$ is the activation polarization, $\eta_{\text {conc,c }}$ is the cathodic concentration polarization, $\eta_{\text {conc,a }}$ is the anodic concentration polarization, and $\eta_{\text {over,anode/YSZ }}$ is the overpotential for oxygen gas evolution at the anode/YSZ interface.

\section{Nernst potential for $M g O$ dissociation, $E_{N}^{M g O}$}

When the Mg produced nucleates in the gaseous state, the Nernst potential for $\mathrm{MgO}$ dissociation is given by $\mathrm{Eq}$. [5], where $E_{\mathrm{N}}^{0, \mathrm{MgO}}$ is the standard Nernst potential for $\mathrm{MgO}$ dissociation $(2.31 \mathrm{~V}),{ }^{[6]} R$ is the gas constant $(8.31$ $\mathrm{J} /(\mathrm{mol} \cdot \mathrm{K})), \quad T$ is the operating temperature $[1423 \mathrm{~K}$ $\left.\left(1150{ }^{\circ} \mathrm{C}\right)\right], F$ is the Faraday constant $(96485 \mathrm{C} / \mathrm{mol})$, $a_{\mathrm{MgO}(\text { flux })}$ is the activity of $\mathrm{MgO}$ dissolved in the flux, $a_{\mathrm{Mg}(\mathrm{g}), \mathrm{c}}$ is the activity of $\mathrm{Mg}$ vapor near the cathode, and $a_{\mathrm{O}_{2}(\mathrm{~g}) \text {,anode/YSZ }}$ is the activity of the evolved $\mathrm{O}_{2}$ at the liquid silver/YSZ interface. During SOM experiment, $\left|E_{\mathrm{N}}^{\mathrm{MgO}}\right|$ was identified at the deflection point of the current-potential curve obtained from PDS between the inert anode current collector and the bubbling tube cathode.

$$
E_{\mathrm{N}}^{\mathrm{MgO}}=E_{\mathrm{N}}^{0, \mathrm{MgO}}+\frac{R T}{2 F} \ln \left[\frac{a_{\mathrm{MgO}(\text { flux })}}{a_{\mathrm{Mg}(\mathrm{g}), \mathrm{c}} \cdot\left(a_{\left.\mathrm{O}_{2}(\mathrm{~g}) \text {,anode } / \mathrm{YSZ}\right)^{\frac{1}{2}}}\right.}\right]
$$

\section{Ohmic polarization, $\eta_{\text {ohm }}$}

The ohmic polarization $\left(\eta_{\mathrm{ohm}}\right)$ of the SOM electrolysis cell could be expressed as follows:

$$
\eta_{\mathrm{ohm}}=i R_{\mathrm{ohm}},
$$

where $i$ is the cell current, and $R_{\mathrm{ohm}}$ is the ohmic resistance of the SOM electrolysis cell. $R_{\mathrm{ohm}}$ can be measured by EIS between the inert anode current collector and the bubbling tube cathode.

\section{Activation polarization, $\eta_{\text {act }}$}

The additional potential needed to overcome the activation energy barrier for the charge transfer reactions at the electrode/electrolyte interface is called activation polarization, $\eta_{\text {act }}$. For small currents and/or rapid mass transfer, it is related to the cell current $i$ by the following Butler-Volmer equation ${ }^{[28-30]}$.

$$
i=i_{0} \exp \left(\frac{\alpha n \eta_{\mathrm{act}} F}{R T}\right)-i_{0} \exp \left(\frac{-(1-\alpha) n \eta_{\mathrm{act}} F}{R T}\right),
$$

where $i_{0}$ is the exchange current, $\alpha$ is the transfer coefficient, and $n=2$ is the number of electrons transferred. Both activation polarizations occurring at the anode and the cathode are lumped together in $\eta_{\text {act }}$. The exchange current $i_{0}$ is a measure of the electrocatalytic activity of the electrode/electrolyte interface for a given electrochemical reaction, and it depends on the operating conditions and materials properties. The transfer coefficient for SOM electrolysis cell is suggested to be 0.5 assuming a symmetric activation energy barrier for both electrode reactions. Then, Eq. [7] can be solved for $\eta_{\text {act }}$ as a function of $i$ :

$$
\eta_{\text {act }}=\frac{R T}{F} \ln \left[\left(\frac{i}{2 i_{0}}\right)+\sqrt{\left(\frac{i}{2 i_{0}}\right)^{2}+1}\right]
$$

\section{Cathodic concentration polarization, $\eta_{\text {conc, } c}$}

The cathodic concentration polarization $\eta_{\text {conc,c }}$ is caused by the mass transport of $\mathrm{MgO}$ across the diffusion layer at the cathode surface and can be expressed as follows ${ }^{[30]}$ : 


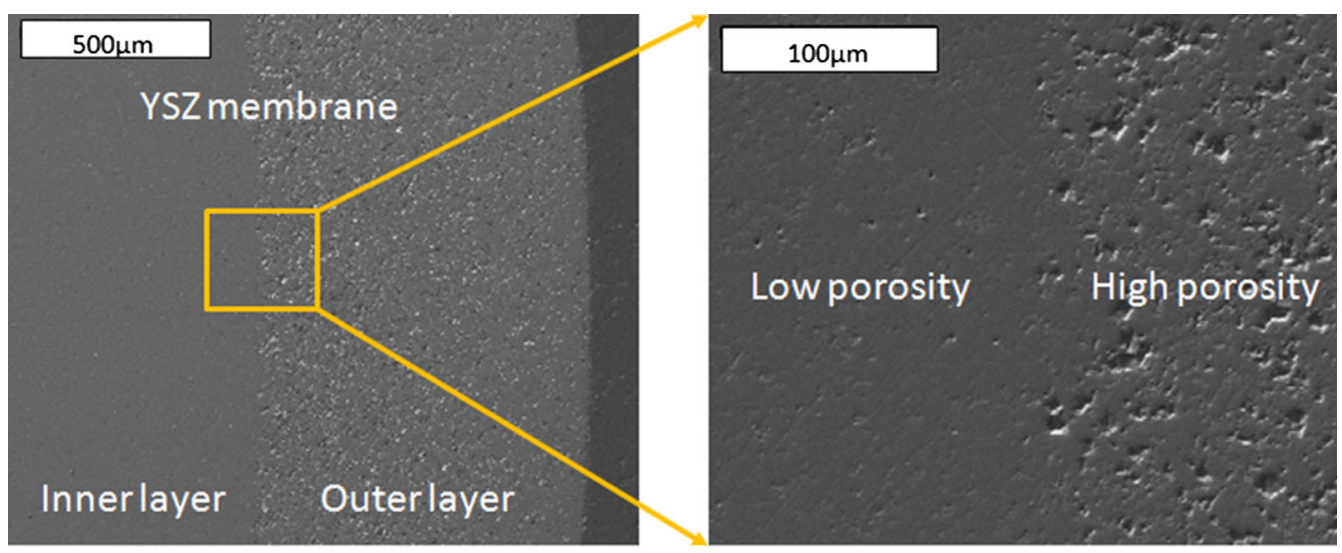

Fig. 7-SEM images of the membrane cross section after the SOM electrolysis.

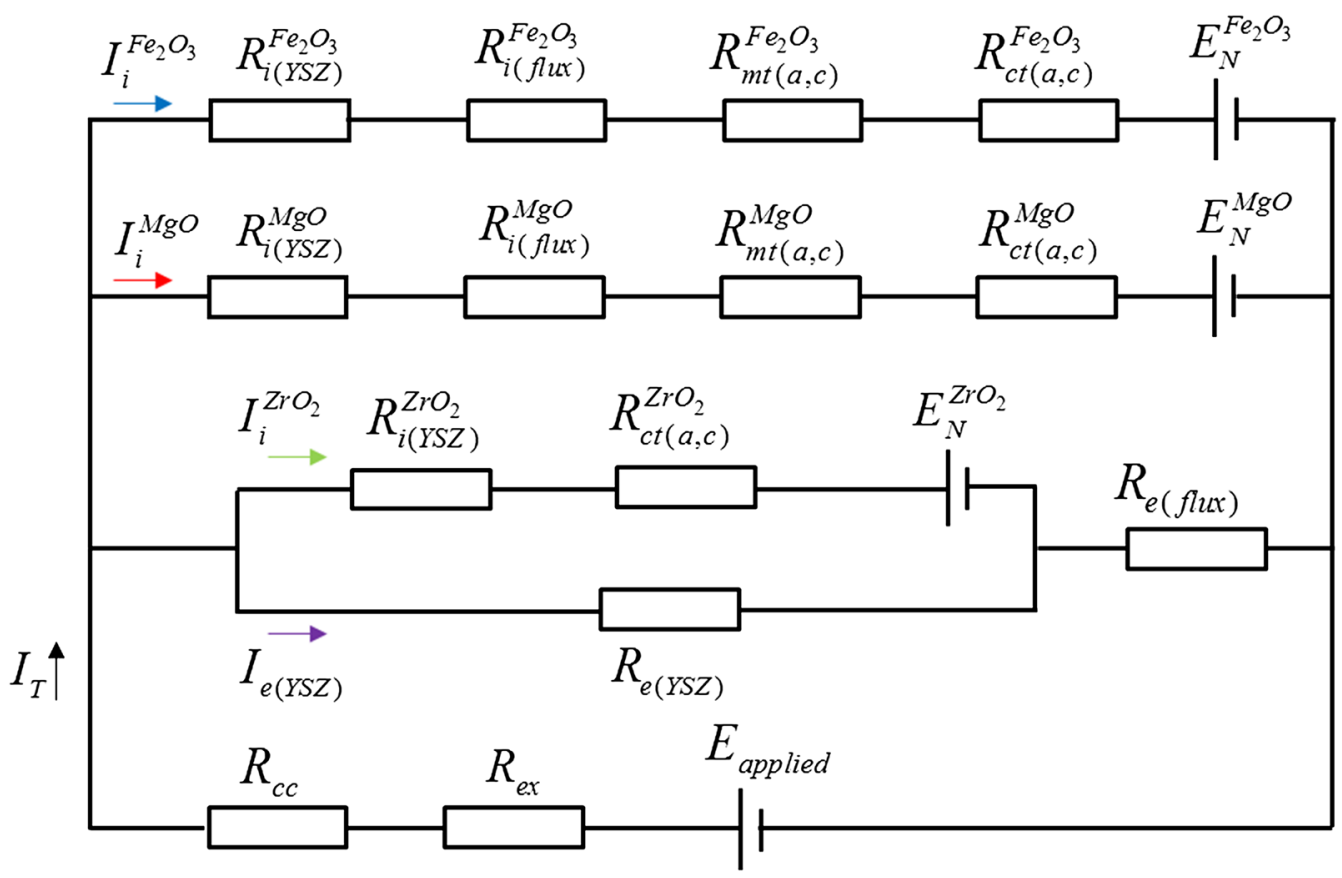

Fig. 8-Equivalent circuit of the SOM electrolysis process for magnesium and oxygen production.

$$
\eta_{\text {conc }, \mathrm{c}}=\frac{R T}{2 F} \ln \left(\frac{a_{\mathrm{MgO}(\text { flux })}^{0}}{a_{\mathrm{MgO}(\text { flux })}^{(\mathrm{i})}}\right),
$$

where $a_{\mathrm{MgO}(\text { flux }}^{0}$ is the activity of $\mathrm{MgO}$ in the bulk flux, and $a_{\mathrm{MgO} \text { (flux) }}^{(\mathrm{i})}$ is the activity of $\mathrm{MgO}$ at the flux/cathode interface under a certain current density. Assuming a Henrian solution, Eq. [9] can be written as follows:

$$
\eta_{\text {conc }, \mathrm{c}}=\frac{R T}{2 F} \ln \left(\frac{C_{\mathrm{MgO}(\text { flux })}^{0}}{C_{\mathrm{MgO}(\text { flux })}^{(\mathrm{i})}}\right),
$$

where $C_{\mathrm{MgO}(\mathrm{flux})}^{0}$ and $C_{\mathrm{MgO}(\mathrm{i}) \mathrm{ux})}^{(\mathrm{i})}$ are the concentrations of $\mathrm{MgO}$ in the bulk flux and at the flux/cathode interface, respectively.
The concentration gradient drives the diffusion of $\mathrm{MgO}$ at the cathodic surface. Assuming a linear concentration gradient within the diffusion layer, the diffusive flux of $\mathrm{MgO}$ at the cathodic surface can be expressed by Fick's first law as follows:

$$
\begin{aligned}
J_{\mathrm{MgO}, \text { flux } / \text { cathode }}= & -D_{\mathrm{MgO}(\text { flux })} \frac{d C_{\mathrm{MgO}(\text { flux })}}{d x}= \\
& -D_{\mathrm{MgO}(\text { flux })} \frac{C_{\mathrm{MgO}(\text { flux })}^{(\mathrm{i})}-C_{\mathrm{MgO} \text { (flux) }}^{0}}{\delta_{\mathrm{c}}}[11]
\end{aligned}
$$

where $D_{\mathrm{MgO} \text { (flux) }}$ is the diffusion coefficient of $\mathrm{MgO}$ in the flux, and $\delta_{\mathrm{c}}$ is the thickness of the diffusion layer at the cathode surface.

Relating the diffusive flux of $\mathrm{MgO}, J_{\mathrm{MgO} \text {,flux/cathode, to }}$ the cell current, $i$, gives 


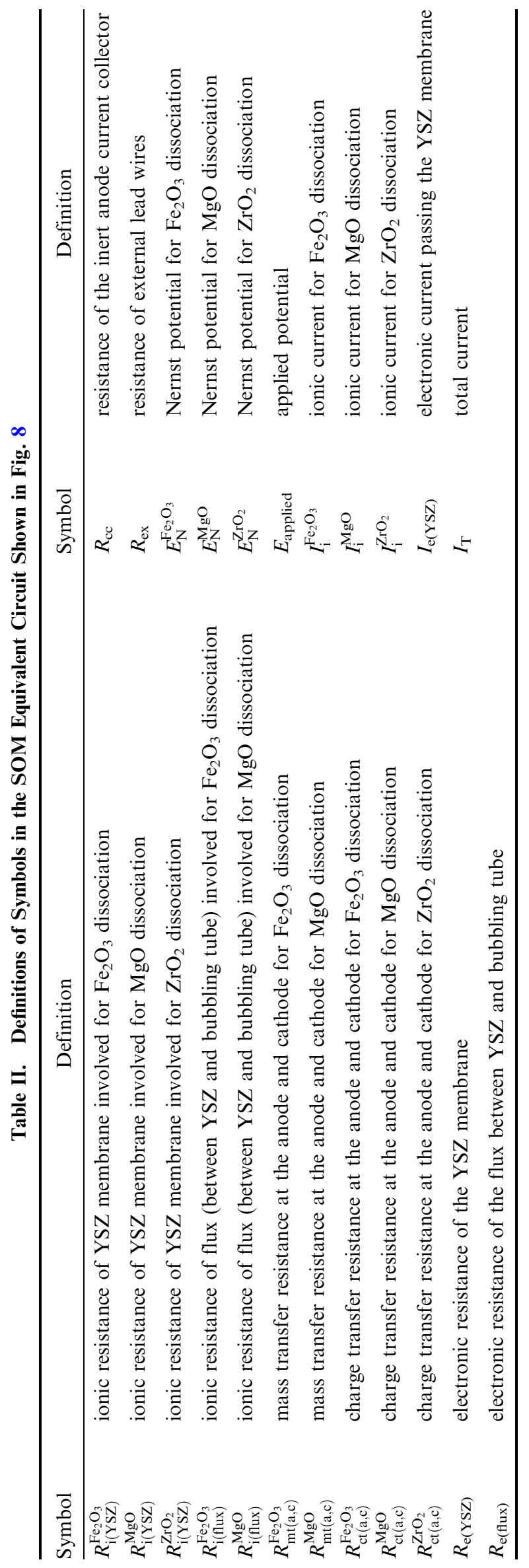

$$
\begin{aligned}
i=2 F A_{\mathrm{c}} & J_{\mathrm{MgO}, \text { flux } / \text { cathode }}= \\
& -2 F A_{\mathrm{c}} D_{\mathrm{MgO}(\text { flux })} \frac{C_{\mathrm{MgO} \text { (flux) }}^{(\mathrm{i})}-C_{\mathrm{MgO} \text { (flux) }}^{0},}{\delta_{\mathrm{c}}}
\end{aligned}
$$

where $A_{\mathrm{c}}$ is the effective cathode's area for the electrochemical half-cell reaction: $\mathrm{Mg}^{2+}+2 \mathrm{e}^{-} \rightarrow \mathrm{Mg}(\mathrm{g})$.

The largest rate of mass transport of $\mathrm{MgO}$ occurs when $C_{\mathrm{MgO}(\mathrm{flux})}^{(\mathrm{i})}=0$. The value of the current under this condition is called the cathodic limiting current, $i_{1, \mathrm{c}}$, where

$$
i_{1, \mathrm{c}}=2 F A_{\mathrm{c}} D_{\mathrm{MgO}(\mathrm{flux})} \frac{C_{\mathrm{MgO}(\mathrm{flux})}^{0}}{\delta_{\mathrm{c}}}
$$

Solving Eqs. [10] through [13], $\eta_{\text {conc,c }}$ can be expressed as follows:

$$
\eta_{\text {conc }, \mathrm{c}}=\frac{R T}{2 F} \ln \left(\frac{i_{1, \mathrm{c}}}{i_{1, \mathrm{c}}-i}\right)
$$

5. Anodic overpotential for $\mathrm{O}_{2}$ evolution, $\eta_{\text {over,anode/YSZ }}$ The liquid silver anode is saturated with oxygen as it is in equilibrium with the oxygen in the air environment. At the liquid silver anode/YSZ interface, oxygen is produced when the applied potential exceeds the electric potential for $\mathrm{MgO}$ dissociation. Oxygen is injected from the YSZ membrane to the liquid silver, and the oxygen partial pressure at the liquid silver anode/YSZ interface reaches $1 \mathrm{~atm}$, equal to the air pressure above the liquid silver. The diffusion of oxygen is slow because the liquid silver is not stirred. In order for the oxygen to form bubbles and leave the liquid silver, the oxygen partial pressure at the liquid silver anode/YSZ interface must exceed $1 \mathrm{~atm}$. This difference in oxygen partial pressure generates an overpotential that must be exceeded to form oxygen bubbles. The overpotential for oxygen gas evolution is expressed as follows:

$$
\begin{aligned}
\eta_{\text {over,anode } / \mathrm{YSZ}}= & \frac{R T}{2 F} \ln \left(\frac{a_{\mathrm{O}_{2}(\mathrm{Ag})}^{\mathrm{b}}}{a_{\mathrm{O}_{2}(\mathrm{Ag})}^{\mathrm{i})}}\right)=\frac{R T}{2 F} \ln \left(\frac{P_{\mathrm{O}_{2}(\mathrm{Ag})}^{\mathrm{b}}}{P_{\mathrm{O}_{2}(\mathrm{Ag})}^{(\mathrm{i})}}\right) \\
= & \frac{R T}{2 F} \ln \left(\frac{P_{\mathrm{O}_{2}(\mathrm{Ag})}^{\mathrm{b}}}{1 \mathrm{~atm}}\right),
\end{aligned}
$$

where $a_{\mathrm{O}_{2}(\mathrm{Ag})}^{\mathrm{b}}$ and $P_{\mathrm{O}_{2}(\mathrm{Ag})}^{\mathrm{b}}$ are the oxygen activity and the oxygen partial pressure required for bubble formation at the liquid silver anode/YSZ interface, respectively; $a_{\mathrm{O}_{2}(\mathrm{Ag})}^{(\mathrm{i})}$ and $P_{\mathrm{O}_{2}(\mathrm{Ag})}^{(\mathrm{i})}$ are the oxygen activity and the oxygen partial pressure at the liquid silver anode/YSZ interface, respectively. Because the oxygen evolved forms bubbles at liquid silver anode/YSZ interface and leaves the liquid silver, there is negligible concentration polarization $\left(\eta_{\text {conc,a }}\right)$ caused by oxygen atom's diffusion in the liquid silver anode. The increasing applied current increases the $\mathrm{O}_{2}$ evolution rate, but does not affect the oxygen partial pressure for bubble formation at the anode/YSZ interface. 
6. Current-potential relationship in polarization model

The general relationship between the applied voltage and the cell current for SOM electrolysis is obtained by substituting Eqs. [6], [8], [14], and [15] into [4]:

$$
\begin{aligned}
E_{\text {applied }}=\mid & E_{\mathrm{N}}^{\mathrm{MgO}} \mid+i R_{\mathrm{ohm}} \\
& +\frac{R T}{F} \ln \left[\left(\frac{i}{2 i_{0}}\right)+\sqrt{\left(\frac{i}{2 i_{0}}\right)^{2}+1}\right] \\
& +\frac{R T}{2 F} \ln \left(\frac{i_{1, \mathrm{c}}}{i_{1, \mathrm{c}}-i}\right)+\frac{R T}{2 F} \ln \left(\frac{P_{\mathrm{O}_{2}(\mathrm{Ag})}^{\mathrm{atm}}}{1 \mathrm{~atm}}\right)
\end{aligned}
$$

The current-potential curve obtained from PDS measurement can be modeled using Eq. [16] to determine various polarization losses and quantify the unknown parameters, such as the exchange current, the cathodic limiting current, and the oxygen partial pressure required for bubble formation at the anode/YSZ interface.

\section{Curve-fitting of the measured current-potential} characteristics

The current-potential curve obtained from the PDS after the pre-electrolysis (the dashed line shown in Figure 3) can be modeled as per the polarization model (Eq. [16]).

The electric potential for $\mathrm{MgO}$ dissociation $\left(\left|E_{\mathrm{N}}^{\mathrm{MgO}}\right|\right)$ producing $\mathrm{Mg}$ vapor at the cathode and $\mathrm{O}_{2}$ at the anode was identified to be $2.08 \mathrm{~V}$, less than $E_{\mathrm{N}}^{0, \mathrm{MgO}}(2.31 \mathrm{~V})$. The explanation for the reduced potential was because the $\mathrm{Ar}$ bubbling through the cathode tube decreased $a_{\mathrm{Mg}(\mathrm{g}) \text {,c. }}{ }^{[20]}$ It is believed that the current observed before reaching $2.08 \mathrm{~V}$ is due to $\mathrm{MgO}$ dissociation resulting in the dissolution of $\mathrm{Mg}$ into the flux as per the reaction: $\mathrm{MgO}=\mathrm{Mg}$ (flux) $+1 / 2 \mathrm{O}_{2}(\mathrm{~g})$. The current at $2.08 \mathrm{~V}$ can be used as the baseline for the curve-fitting. The difference between the measured current and the baseline current in the potential ranging from $2.08 \mathrm{~V}$ to $3.32 \mathrm{~V}$ is referred to as the net current. The ohmic resistance of the SOM cell $\left(R_{\mathrm{ohm}}\right)$ was measured to be $0.54 \Omega$ (see Figure 2).

Mass-transfer-limited behavior was not observed (see the PDS after pre-electrolysis in Figure 3). Consequently, the anodic and the cathodic concentration polarizations can be ignored. Equation [16] can be written as follows:

$$
\begin{aligned}
E_{\text {applied }}=\left|E_{\mathrm{N}}^{\mathrm{MgO}}\right| & +i R_{\mathrm{ohm}} \\
& +\frac{R T}{F} \ln \left[\left(\frac{i}{2 i_{0}}\right)+\sqrt{\left(\frac{i}{2 i_{0}}\right)^{2}+1}\right] \\
& +\frac{R T}{2 F} \ln \left(\frac{P_{\mathrm{O}_{2}(\mathrm{Ag})}^{\mathrm{atm}}}{1 \mathrm{~atm}}\right)
\end{aligned}
$$

The experimental data of the applied potential and the net current were curved fitted into Eq. [17]. The exchange current, $i_{0}$, and the oxygen partial pressure for bubble formation at the anode/YSZ interface, $P_{\mathrm{O}_{2}(\mathrm{Ag})}^{\mathrm{b}}$, were treated as the fitting parameters, and the results are shown

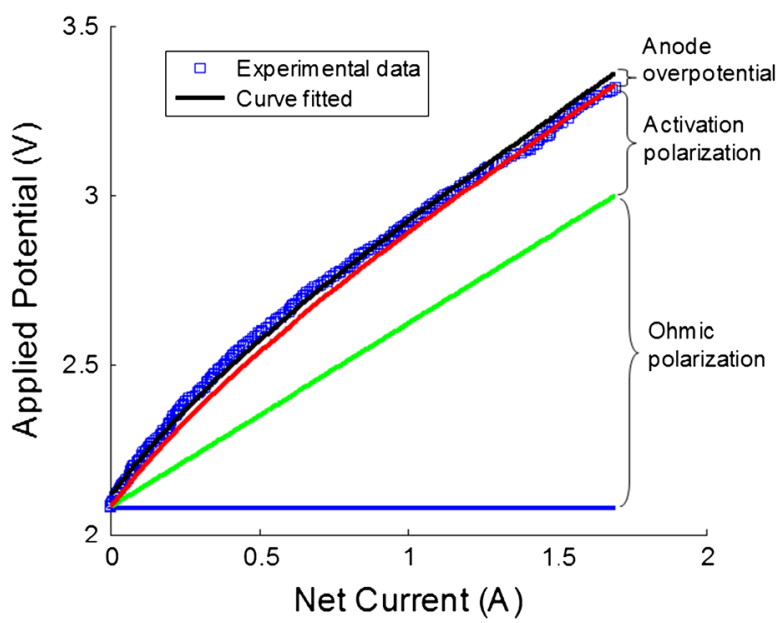

Fig. 9-The ohmic overpotential and the activation polarization as a function of the net current by modeling on the SOM electrolysis cell (Color figure online).

in Figure 9. The good match between the experimental data and the fitted curves justify the assumption that the concentration polarizations are negligible. The exchange current obtained from the curve fitting was $0.1154 \mathrm{~A}$. Prior studies have shown that the charge transfer reaction at the interface between liquid metal electrode and the YSZ electrolyte is very fast. ${ }^{[31-33]}$ Therefore, the exchange current value is believed to be limited by the cathodic material's structure and surface roughness, the concentration of $\mathrm{MgO}$ at the cathodic surface, etc. The charge transfer resistance at the cathode for $\mathrm{MgO}$ dissociation $\left(R_{\mathrm{ct}, \mathrm{c}}^{\mathrm{MgO}}\right)$ can be evaluated from the polarization model. $R_{\mathrm{ct}, \mathrm{c}}^{\mathrm{MgO}}$ is the differential of the activation polarization $\left(\eta_{\text {act }}\right)$ with respect to the ionic current for $\mathrm{MgO}$ dissociation $\left(I_{\mathrm{i}}^{\mathrm{MgO}}\right)$, as expressed by Eq. [18]. ${ }^{[34]}$

$$
R_{\mathrm{ct}, \mathrm{c}}^{\mathrm{MgO}}=\left.\frac{d \eta_{\mathrm{act}}}{d i}\right|_{i=I_{\mathrm{i}}^{\mathrm{MgO}}}=\frac{R T}{F} \frac{1}{\sqrt{\left(I_{\mathrm{i}}^{\mathrm{MgO}}\right)^{2}+\left(2 i_{0}\right)^{2}}}
$$

When the electrolysis cell is at equilibrium $\left(I_{\mathrm{i}}^{\mathrm{MgO}}=0\right), R_{\mathrm{ct}, \mathrm{c}}^{\mathrm{MgO}}$ is given as Eq. [19], and it is equal to $0.531 \Omega$.

$$
R_{\mathrm{ct}, \mathrm{c}}^{\mathrm{MgO}}=\left.\frac{d \eta_{\mathrm{act}}}{d i}\right|_{i=0}=\frac{R T}{2 F i_{0}}
$$

The oxygen partial pressure for bubble formation at the anode/YSZ interface, $P_{\mathrm{O}_{2}(\mathrm{Ag})}^{\mathrm{b}}$, obtained from the curve fitting was $1.747 \mathrm{~atm}$. The $\mathrm{O}_{2}$ bubble radius $(r)$ was calculated to be $17.6 \mu \mathrm{m}$ using the following equation ${ }^{[35]}$ :

$$
P_{\mathrm{O}_{2}(\mathrm{Ag})}^{\mathrm{b}}-P_{\mathrm{Ag}}^{\text {out }}=\frac{2 \sigma}{r},
$$

where $P_{\mathrm{Ag}}^{\text {out }}=1 \mathrm{~atm}$ is the hydrostatic pressure outside $\mathrm{O}_{2}$ bubble in liquid silver, and $\sigma=658 \times 10^{-3} \mathrm{~N} / \mathrm{m}$ is the surface tension of liquid silver at the oxygen partial 
pressure of $1 \mathrm{~atm}$ at $1423 \mathrm{~K}\left(1150{ }^{\circ} \mathrm{C}\right) \cdot{ }^{[36]} \mathrm{It}$ is to be noted that as $\mathrm{O}_{2}$ bubble rises through the liquid silver, the pressure inside the oxygen bubble decreases, and therefore the volume of $\mathrm{O}_{2}$ bubble increases. In addition, the volume of oxygen bubble might also increase due to multiple oxygen bubbles coalescing and merging.

Based on the curve fitting results, the ohmic polarization and the activation polarization were calculated as a function of current, and the results are also shown in Figure 9. In the current ranging from 1 to $1.7 \mathrm{~A}$, the contributions from ohmic resistance and the charge transfer resistance to the total polarization were $\sim 70$ and $\sim 30$ pct, respectively; the contribution from the anodic overpotential for $\mathrm{O}_{2}$ gas evolution $(0.0342 \mathrm{~V})$ is much smaller. The ohmic polarization was therefore dominating the total polarization in this current regime. This indicated that the performance of the SOM electrolysis can be improved by reducing the ohmic resistance, which can be realized by decreasing the thickness of the electrolyte (the YSZ membrane and the flux). The concentration polarizations were insignificant in the current ranging from 0 to 1.7 A. However, if the current continues to increase and approach the cathodic limiting current, then the contribution from the cathodic concentration polarization to the total polarization would become non-negligible. In that case, the cathodic concentration polarization should be considered in the modeling.

\section{Maximum Allowable Applied Potential}

As SOM electrolysis continues, more $\mathrm{Mg}$ dissolves into the flux, and thus the electronic conductivity of the flux increases. The dissolved $\mathrm{Mg}$ provides a pathway for the electronic current in the flux. There are both electronic and ionic currents passing through the flux and the YSZ membrane (see the equivalent circuit in Figure 8). As previously described, the increased electronic conductivity of the flux decreased the electronic potential drop across the flux and increased the potential drop across the YSZ membrane when a constant DC electric potential is applied across the entire cell. To avoid $\mathrm{ZrO}_{2}$ dissociation, the potential drop across the YSZ membrane $\left(I_{\mathrm{e}(\mathrm{YSZ})} \cdot R_{\mathrm{e}(\mathrm{YSZ})}\right)$ should not exceed the electric potential for $\mathrm{ZrO}_{2}$ dissociation,

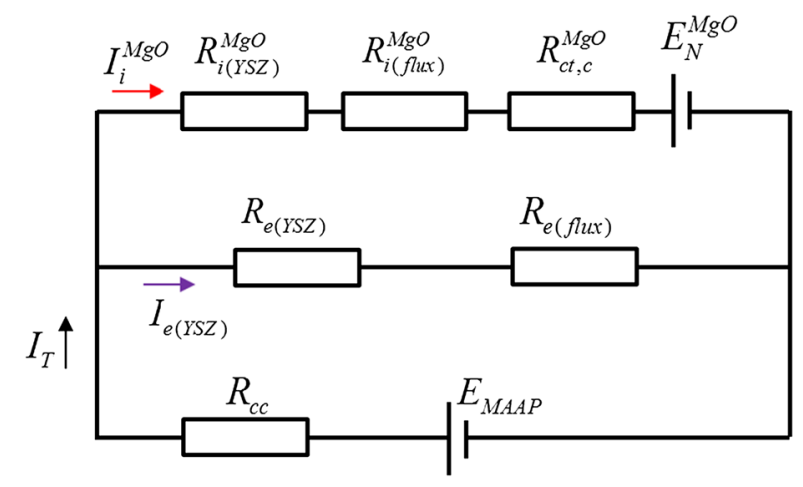

Fig. 10-The simplified equivalent circuit for SOM process when the applied potential is the maximum allowable applied potential, $E_{\text {MAAP. }}$ which is also the absolute value of the Nernst potential for $\mathrm{ZrO}_{2}$ dissociation, $\left|E_{\mathrm{N}}^{\mathrm{ZrO}_{2}}\right|$. When the potential drop across the YSZ membrane is equal to $\left|E_{\mathrm{N}}^{\mathrm{ZrO}_{2}}\right|$, as expressed by Eq. [21], the ionic current for $\mathrm{ZrO}_{2}$ dissociation, $I_{\mathrm{i}}^{\mathrm{ZrO}_{2}}$ becomes zero. In this case, the applied potential is defined as the maximum allowable applied potential $\left(E_{\mathrm{MAAP}}\right)$ to avoid $\mathrm{ZrO}_{2}$ dissociation.

$$
I_{\mathrm{e}(\mathrm{YSZ})} \cdot R_{\mathrm{e}(\mathrm{YSZ})}=\left|E_{\mathrm{N}}^{\mathrm{ZrO}_{2}}\right|
$$

\section{Analysis of simplified equivalent circuit}

To calculate $E_{\mathrm{MAAP}}$, it is necessary to simplify the equivalent circuit in Figure 8. According to the polarization model, the mass transfer resistances for $\mathrm{MgO}$ dissociation are negligible at the current ranging from 0 to $1.7 \mathrm{~A}$. At the point when $\mathrm{Mg}$ dissolves in the flux and imparts electronic conductivity to the flux, the entire $\mathrm{Fe}_{2} \mathrm{O}_{3}$ must have already been removed. Therefore, the circuit branch for $\mathrm{Fe}_{2} \mathrm{O}_{3}$ dissociation can be eliminated. In addition, resistance of external lead wires $\left(R_{\mathrm{ex}}\right)$ was negligible. The simplified equivalent circuit is shown in Figure 10.

According to the Kirchhoff's Current Law (KCL),

$$
I_{\mathrm{T}}=I_{\mathrm{i}}^{\mathrm{MgO}}+I_{\mathrm{e}(\mathrm{YSZ})}
$$

The Kirchhoff's Voltage Law applied to the closed circuits in the simplified equivalent circuit gives

$$
\begin{gathered}
E_{\mathrm{MAAP}}=I_{\mathrm{T}} \cdot R_{\mathrm{cc}}+I_{\mathrm{e}(\mathrm{YSZ})} \cdot\left(R_{\mathrm{e}(\mathrm{YSZ})}+R_{\mathrm{e}(\text { flux })}\right) \\
E_{\mathrm{MAAP}}=I_{\mathrm{T}} \cdot R_{\mathrm{cc}}+I_{\mathrm{i}}^{\mathrm{MgO}} \cdot\left(R_{\mathrm{i}(\mathrm{YSZ})}^{\mathrm{MgO}}+R_{\mathrm{i}(\mathrm{flux})}^{\mathrm{MgO}}+R_{\mathrm{ct}, \mathrm{c}}^{\mathrm{MgO}}\right) \\
+\left|E_{\mathrm{N}}^{\mathrm{MgO}}\right|
\end{gathered}
$$

Equations [21] through [24] are independent, and they form a system of equations in the four unknown parameters $I_{\mathrm{e}(\mathrm{YSZ})}, I_{\mathrm{T}}, I_{\mathrm{i}}^{\mathrm{MgO}}$, and $E_{\mathrm{MAAP}}$. When the applied potential is $E_{\mathrm{MAAP}}$, the current efficiency (CE) can be represented as

$$
\mathrm{CE}=\frac{I_{\mathrm{i}}^{\mathrm{MgO}}}{I_{\mathrm{T}}}
$$

\section{Quantification of $E_{M A A P}$}

To quantify $E_{\text {MAAP }}$ for the SOM experiment described in this article, the values of the parameters $\left(\left|E_{\mathrm{N}}^{\mathrm{ZrO}}{ }_{2}\right|, R_{\mathrm{cc}}, R_{\mathrm{i}(\mathrm{YSZ})}^{\mathrm{MgO}}, R_{\mathrm{i}(\text { (flux) }}^{\mathrm{MgO}}, R_{\mathrm{e}(\text { flux })}\right.$, and $\left.R_{\mathrm{e}(\mathrm{YSZ})}\right)$ in the system of equations need to be either measured during the experiment or calculated based on the available literature data. $\left|E_{\mathrm{N}}^{\mathrm{ZrO}_{2}}\right|$ can be calculated according to the Nernst equation as follows:

$$
E_{\mathrm{N}}^{\mathrm{ZrO}_{2}}=E_{\mathrm{N}}^{0, \mathrm{ZrO}_{2}}+\frac{R T}{4 F} \ln \left(\frac{a_{\mathrm{ZrO}_{2}(\mathrm{~s})}}{a_{\mathrm{Zr}(\mathrm{s})} a_{\mathrm{O}_{2}(\mathrm{~g}), \text { anode } / \mathrm{YSZ}}}\right),
$$

where $E_{\mathrm{N}}^{0, \mathrm{ZrO}_{2}}=-2.153 \mathrm{~V}$ is the standard Nernst potential for $\mathrm{ZrO}_{2}$ dissociation at $T=1423 \mathrm{~K}\left(1150{ }^{\circ} \mathrm{C}\right)^{[37]}$; $a_{\mathrm{ZrO}_{2}(\mathrm{~s})}$ and $a_{\mathrm{Zr}(\mathrm{s})}$ are the activities of the solid $\mathrm{ZrO}_{2}$ and 
$\mathrm{Zr}$ at the cathode side of the YSZ membrane, and they are both equal to unity; and $a_{\mathrm{O}_{2}(\mathrm{~g}) \text {,anode/YSZ is the activity }}$ of oxygen bubble at the anode Y YSZ interface, and it is equal to 1.747 . Therefore, $\left|E_{\mathrm{N}}^{\mathrm{ZrO}_{2}}\right|$ is equal to $2.17 \mathrm{~V}$.

The ohmic resistance of the LSM-Inconel current collector has been reported to be approximately $0.125 \Omega$ at $1423 \mathrm{~K}\left(1150{ }^{\circ} \mathrm{C}\right)$ in earlier experiments. ${ }^{[6]}$ Because of similar cell constants, the ohmic resistance of the LSMInconel current collector used in this SOM experiment $\left(R_{\mathrm{cc}}\right)$ is estimated to be $0.125 \Omega$.

The ionic resistance of the YSZ membrane $\left(R_{\mathrm{i}(\mathrm{YSZ})}\right)$ depends on the ionic conductivity $\left(\sigma_{\mathrm{i}(\mathrm{YSZ})}\right)$, the crosssectional area $(A(x))$, and the thickness of the YSZ membrane $\left(L_{\mathrm{YSZ}}\right)$ as shown in Eq. [27].

$$
R_{\mathrm{i}(\mathrm{YSZ})}=\int_{0}^{L_{\mathrm{YSZ}}} \frac{1}{\sigma_{\mathrm{i}(\mathrm{YSZ})}} \frac{d x}{A(x)}
$$

Filal et al. ${ }^{[38]}$ have reported the ionic conductivities of the YSZ membrane with different amounts of $\mathrm{Y}_{2} \mathrm{O}_{3}(3$ and $9.5 \mathrm{~mol} \mathrm{pct}$ ). In this work, $6 \mathrm{~mol}$ pet YSZ membrane was employed, and its ionic conductivity at $1423 \mathrm{~K}\left(1150{ }^{\circ} \mathrm{C}\right)$ is estimated to be $21.88 \mathrm{~S} / \mathrm{m}$ by interpolation from the literature data. The ionic resistance of the YSZ membrane is calculated to be $0.071 \Omega$.

The cell ohmic resistance was measured to be $0.54 \Omega$ at the beginning of the experiment. No $\mathrm{Mg}$ was dissolved in the flux yet, and so the electronic resistances of the YSZ membrane and the flux were much higher than their ionic resistances. The contact resistance associated with all the interfaces and the ohmic resistances of the external lead wires are assumed to be negligible. Therefore, the ionic resistance of the flux between the bubbling tube and the YSZ membrane $\left(R_{\mathrm{i}(\mathrm{flux})}^{\mathrm{MgO}}\right)$ is calculated to be $0.344 \Omega$ by subtracting $R_{\mathrm{i}(\mathrm{YSZ})}(0.071 \Omega)$ and $R_{\mathrm{cc}}(0.125 \Omega)$ from $R_{\text {ohm }}(0.54 \Omega)$. The value of $R_{\mathrm{i}(\text { flux })}^{\mathrm{MgO}}$ was expected to be stable during the experiment because $\mathrm{MgO}$ concentration change in the flux was negligibly small.

To calculate the electronic resistance of the flux $\left(R_{\mathrm{e}(f l u x)}\right)$ between the bubbling tube and the YSZ membrane, Eq. [3] can be rearranged into Eq. [28] to write $R_{\mathrm{e}(f l u x)}$ as a function of $R_{\mathrm{i} \text { (flux) }}^{\mathrm{MgO}}$ and $t_{\mathrm{e} \text { (flux). }}$.

$$
R_{\mathrm{e}(\mathrm{flux})}=R_{\mathrm{i} \text { (flux) }}^{\mathrm{MgO}}\left(\frac{1}{t_{\mathrm{e}(\text { flux })}}-1\right)
$$

As the flux was stirred by bubbling gas, $t_{\mathrm{e}(\mathrm{flux})}$ between the bubbling tube and the YSZ membrane is equal to $t_{\mathrm{e}(\mathrm{flux})}$ between the bubbling tube and the reaction chamber (see Table II). Therefore, $R_{\mathrm{e}(\mathrm{flux})}$ between the bubbling tube and the YSZ membrane can be calculated and the values are listed in Table III.

The electronic resistance of the YSZ membrane $\left(R_{\mathrm{e}(\mathrm{YSZ})}\right)$ depends on the electronic conductivity $\left(\sigma_{\mathrm{e}, \mathrm{YSZ}}\right)$, $A(x)$, and $L_{\mathrm{YSZ}}$ as shown in the following equation:

$$
R_{\mathrm{e}(\mathrm{YSZ})}=\int_{0}^{L_{\mathrm{YSZ}}} \frac{1}{\sigma_{\mathrm{e}(\mathrm{YSZ})}} \frac{d x}{A(x)}
$$




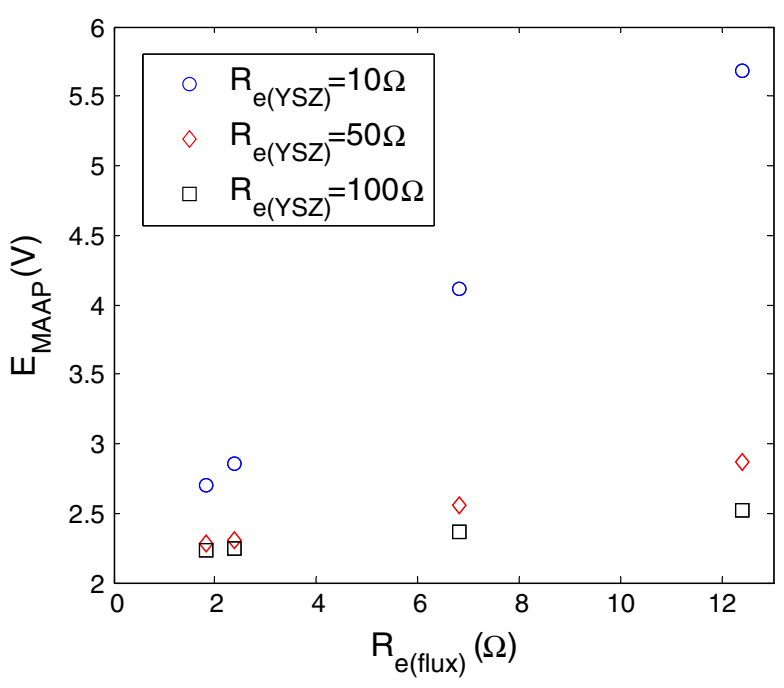

Fig. 11-The calculated $E_{\mathrm{MAAP}}$ as a function of $R_{\mathrm{e}(\mathrm{flux})}$ for different values of $R_{\mathrm{e}(\mathrm{YSZ})}$.

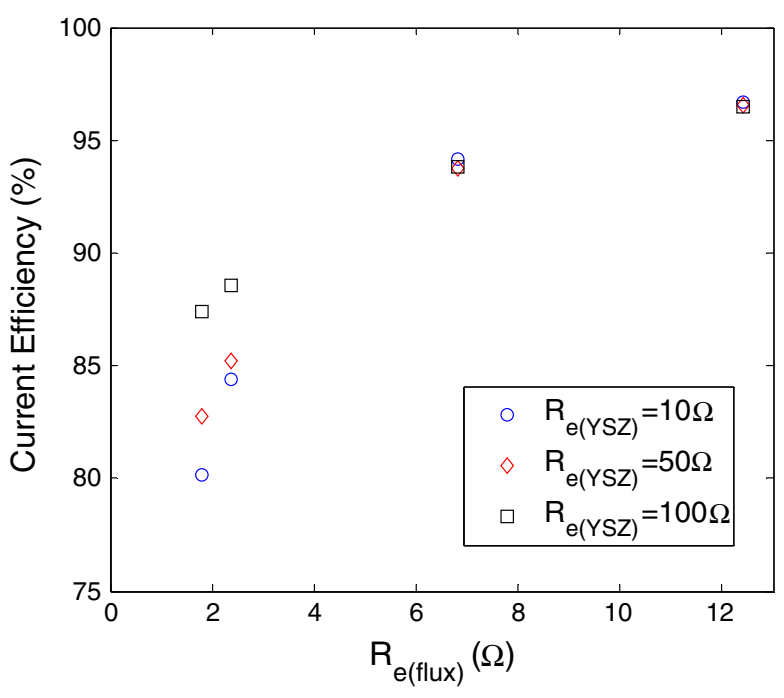

Fig. 12-The calculated current efficiency as a function of $R_{\mathrm{e}(f l u x)}$ for different values of $R_{\mathrm{e}(\mathrm{YSZ})}$ when the applied potential is $E_{\mathrm{MAAP}}$.

Park et al. ${ }^{[27]}$ has reported that $\sigma_{\mathrm{e}, \mathrm{YSZ}}$ depends on the oxygen partial pressure distribution in the YSZ membrane. The oxygen partial pressure in the YSZ membrane during the SOM electrolysis is still ambiguous. Therefore, instead of calculating $R_{\mathrm{e}(\mathrm{YSZ})}$, it is more realistic to take a series of trial values $(10 \Omega, 50 \Omega$, and $100 \Omega$ ) of $R_{\mathrm{e}(\mathrm{YSZ})}$. The above trial values are chosen to obtain current efficiencies in the range that is experimentally observed (from 75 to 95 pct) and also the ionic currents for $\mathrm{MgO}$ dissociation when the applied potential is $E_{\text {MAAP. }}$ The values of the parameters used to calculate the unknown parameters $\left(I_{\mathrm{e}(\mathrm{YSZ})}, I_{\mathrm{T}}, I_{\mathrm{i}}^{\mathrm{MgO}}\right.$, and $\left.E_{\mathrm{MAAP}}\right)$ are given in Table III.

Figure 11 shows the calculated $E_{\mathrm{MAAP}}$ as a function of $R_{\mathrm{e}(\mathrm{flux})}$ for different values of $R_{\mathrm{e}(\mathrm{YSZ})}$. The calculated $E_{\mathrm{MAAP}}$ decreases as $R_{\mathrm{e}(\mathrm{flux})}$ decreases for each value of $R_{\mathrm{e}(\mathrm{YSZ})}$. As more $\mathrm{Mg}$ dissolves into the flux,

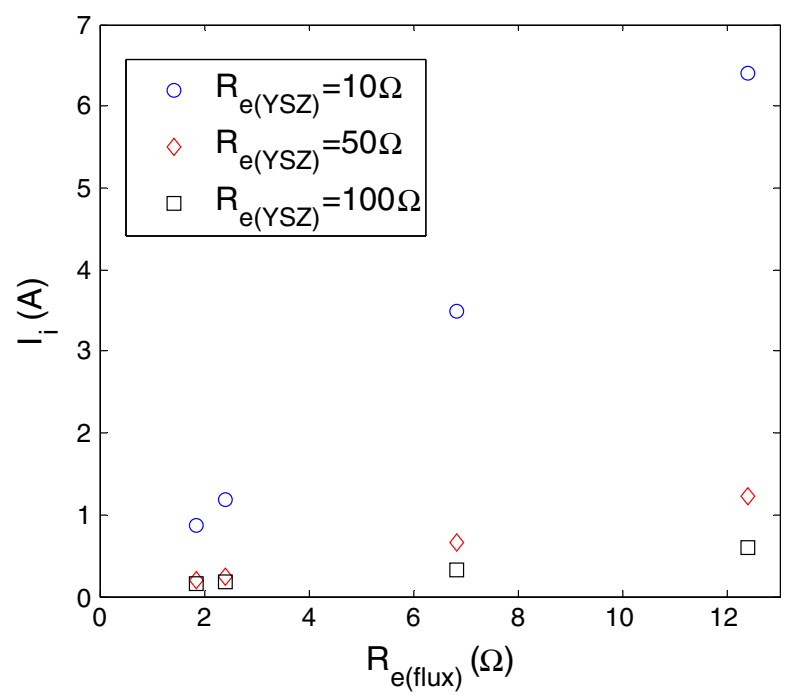

Fig. 13- The calculated ionic current for $\mathrm{MgO}$ dissociation $\left(I_{\mathrm{i}}^{\mathrm{MgO}}\right)$ as a function of $R_{\mathrm{e}(\mathrm{flux})}$ for different values of $R_{\mathrm{e}(\mathrm{YSZ})}$ when the applied potential is $E_{\text {MAAP. }}$.

$R_{\mathrm{e}(\mathrm{flux})}$ becomes smaller, and thus $E_{\mathrm{MAAP}}$ becomes smaller as well. During the SOM experiment, $R_{\mathrm{e}(\mathrm{flux})}$ can be monitored, and applied potential can be adjusted accordingly to avoid $\mathrm{ZrO}_{2}$ dissociation. In addition, $E_{\mathrm{MAAP}}$ can be increased by increasing $R_{\mathrm{e}(\mathrm{flux})}$. This can be accomplished by operating the SOM electrolysis cell at low total pressures which is an effective method of removing $\mathrm{Mg}$ dissolved in the flux and reducing the electronic conductivity of the flux. ${ }^{[20]}$ Figure 11 also shows that the calculated $E_{\mathrm{MAAP}}$ increases as $R_{\mathrm{e}(\mathrm{YSZ})}$ decreases for each value of $R_{\mathrm{e}(\mathrm{flux})}$. It suggests that $E_{\mathrm{MAAP}}$ can be increased by decreasing $R_{\mathrm{e}(\mathrm{YSZ})}$. This can be realized by reducing the thickness of the YSZ membrane and/or increasing the cross-sectional area of the YSZ membrane. Another method is to make the YSZ membrane more mixed conducting or to employ a different mixed-conducting membrane that conducts both oxygen ions and electrons.

Figure 12 shows the calculated current efficiency as a function of $R_{\mathrm{e}(\mathrm{flux})}$ for different values of $R_{\mathrm{e}(\mathrm{YSZ})}$ when the applied potential is $E_{\text {MAAP. }}$. It should be noted that in this modeling the applied potential $\left(E_{\mathrm{MAAP}}\right)$ varies with both $R_{\mathrm{e}(\mathrm{flux})}$ and $R_{\mathrm{e}(\mathrm{YSZ})}$ (see Figure 11 ). For same $R_{\mathrm{e}(\mathrm{YSZ})}$, the calculated current efficiency decreases as $R_{\mathrm{e}(\mathrm{flux})}$ decreases, consistent with the experimental results in this work. Figure 12 also shows that when $R_{\text {e(flux) }}$ is greater than $6 \Omega$, the current efficiency is independent of $R_{\mathrm{e}(\mathrm{YSZ})}$. When $R_{\mathrm{e}(\mathrm{YSZ})}$ is small, the current efficiency increases with the increasing $R_{\mathrm{e}(\mathrm{YSZ})}$. This is because the electronic current in the flux is blocked by the YSZ membrane. Therefore, $R_{\mathrm{e}(\mathrm{YSZ})}$ cannot be too small in order to maintain a high current efficiency of the SOM electrolysis process.

In addition to current efficiency, the performance of the SOM electrolysis can also be evaluated by the production rates of $\mathrm{Mg}$ and $\mathrm{O}_{2}$, which are linearly proportional to the ionic current for $\mathrm{MgO}$ dissociation $\left(\mathrm{I}_{\mathrm{i}}^{\mathrm{MgO}}\right)$. Figure 13 shows the calculated $I_{\mathrm{i}}^{\mathrm{MgO}}$ as a function of $R_{\mathrm{e}(\mathrm{flux})}$ for different values of $R_{\mathrm{e}(\mathrm{YSZ})}$ when the applied potential is 
$E_{\mathrm{MAAP}}$. The dependence of $I_{i}^{\mathrm{MgO}}$ on $R_{\mathrm{e}(\mathrm{flux})}$ and $R_{\mathrm{e}(\mathrm{YSZ})}$, is similar to that of $E_{\mathrm{MAAP}}$. A high $R_{\mathrm{e}(\mathrm{flux})}$ and a low $R_{\mathrm{e}(\mathrm{YSZ})}$ allow for a high $E_{\mathrm{MAAP}}$, and thus a high $I_{\mathrm{i}}^{\mathrm{MgO}}$ according to the simplified equivalent circuit in Figure 10.

Overall, a high $R_{\mathrm{e}(\mathrm{flux})}$ and a relatively low $R_{\mathrm{e}(\mathrm{YSZ})}$ are required to achieve $\mathrm{ZrO}_{2}$ stability, high current efficiency, and high production rate of $\mathrm{Mg}$ and $\mathrm{O}_{2}$.

\section{CONCLUSIONS}

SOM electrolysis experiment was successfully performed in producing $\mathrm{Mg}$ at the cathode and $\mathrm{O}_{2}$ at the anode. Dissolved Mg metal was responsible for imparting electronic conductivity to the flux. An inverse correlation between the electronic transference number of the flux and the current efficiency of the SOM electrolysis was observed. Based on the experimental results, a new equivalent circuit of the SOM electrolysis process was presented by taking into account the dissociations of $\mathrm{Fe}_{2} \mathrm{O}_{3}, \mathrm{MgO}$, and $\mathrm{ZrO}_{2}$, and the impact of the electronic conductivity in the flux. In addition, a polarization model for $\mathrm{Mg}$ and $\mathrm{O}_{2}$ production was developed to analyze various polarization losses. The maximum allowable applied potential $\left(E_{\mathrm{MAAP}}\right)$ to avoid $\mathrm{ZrO}_{2}$ dissociation was quantified as a function of the electronic resistance of the flux $\left(R_{\mathrm{e}(\text { flux })}\right)$ for different values of electronic resistance of the YSZ membrane $\left(R_{\mathrm{e}(\mathrm{YSZ})}\right)$. A high $R_{\mathrm{e}(\text { flux })}$ and a relatively low $R_{\mathrm{e}(\mathrm{YSZ})}$ are required to achieve $\mathrm{ZrO}_{2}$ stability, high current efficiency, and high production rates of $\mathrm{Mg}$ and $\mathrm{O}_{2}$.

\section{ACKNOWLEDGMENTS}

This research is based upon work supported by the Department of Energy under Award No. DE-EE0005547. The authors would like to thank Dr. Eric Gratz for helpful discussions.

\section{REFERENCES}

1. U.B. Pal, D.E. Woolley, and G.B. Kenney: JOM, 2001, vol. 53 (10), pp. 32-35.

2. A. Krishnan, U.B. Pal, and X.G. Lu: Metall. Mater. Trans. B, 2005, vol. 36B, pp. 463-73.

3. U.B. Pal and A.C. Powell: JOM, 2007, vol. 59 (5), pp. 44-49.

4. X. Guan, P.A. Zink, U.B. Pal, and A.C. Powell: Metall. Mater. Trans. B, 2013, vol. 44B, pp. 261-71.

5. X. Guan, U.B. Pal, and A.C. Powell: JOM, 2013, vol. 65 (10), pp. 1285-92.
6. X. Guan, U.B. Pal, S. Gopalan, and A.C. Powell: J. Electrochem. Soc., 2013, vol. 160 (11), pp. F1179-86.

7. S. Das: $J O M, 2008$, vol. 60 (11), pp. 63-69.

8. M. Suput, R. Delucas, S. Pati, G. Ye, U. Pal, and A.C. Powell, IV: Miner. Process. Extr. Metall., 2008, vol. 117 (2), pp. 118-22.

9. A. Krishnan, X.G. Lu, and U.B. Pal: Scand. J. Metall., 2005, vol. 34 (5), pp. 293-301.

10. S. Pati, R. Delucas, and U.B. Pal: in EPD Congress 2008, S.M. Howard, ed., TMS, Warrendale, PA, 2008, pp. 121-26.

11. Y. Jiang, P.A. Zink, and U.B. Pal: ECS Trans., 2012, vol. 41 (33), pp. 171-80.

12. Y. Jiang, J. Xu, X. Guan, U.B. Pal, and S.N. Basu: MRS Proc., 2013, vol. 1493, pp. 231-35.

13. A. Roan, S. Pati, S.N. Basu, and U.B. Pal: TMS Supplemental Proceeding, Vol. 1: Materials Processing and Energy Materials, Wiley, New Jersey, 2011, pp. 717-21.

14. X. Lu, X. Zou, C. Li, Q. Zhong, W. Ding, and Z. Zhou: Metall. Mater. Trans. B, 2012, vol. 43B, pp. 503-12.

15. B. Zhao, X. Lu, Q. Zhong, C. Li, and S. Chen: Electrochim. Acta, 2010, vol. 55 (8), pp. 2996-3001.

16. X. Zou, X. Lu, C. Li, and Z. Zhou: Electrochim. Acta, 2010, vol. 55 (18), pp. 5173-79.

17. X. Zou, X. Lu, Z. Zhou, C. Li, and W. Ding: Electrochim. Acta, 2011, vol. 56 (24), pp. 8430-37.

18. E. Gratz, S. Pati, J. Milshtein, A. Powell, and U. Pal: Electrometallurgy 2012 (TMS), M.L. Free, M. Moats, G. Houlachi, E. Asselin, A. Allanore, J. Yurko, and S. Wang, eds., Wiley, New Jersey, 2012, pp. 111-18.

19. A. Dworkin and M. Bredig: J. Phys. Chem., 1971, vol. 75 (15), pp. $2340-44$.

20. E. Gratz: Ph.D. Dissertation, Boston University, 2013.

21. E.S. Gratz, J.D. Milshtein, and U.B. Pal: J. Am. Ceram. Soc., 2013, vol. 96 (10), pp. 3279-85.

22. P. Chartrand and A.D. Pelton: Metall. Mater. Trans. A, 2001, vol. 32A, pp. 1385-96.

23. T.H. Etsell and S.N. Flengas: Metall. Trans., 1971, vol. 2 (10), pp. 2829-32.

24. S.C. Britten and U.B. Pal: Metall. Mater. Trans. B, 2000, vol. 31B, pp. $733-53$.

25. K.R. Copper and M. Smith: J. Power Sources, 2006, vol. 160, pp. 1088-95.

26. A.V. Virkar: J. Power Sources, 2005, vol. 147 (1-2), pp. 8-31.

27. J. Park and R.N. Blumenthal: J. Electrochem. Soc., 1989, vol. 136 (10), pp. 2867-76.

28. S. Pati, K.J. Yoon, S. Gopalan, and U.B. Pal: Metall. Mater. Trans. B, 2009, vol. 40B, pp. 1041-53.

29. K.J. Yoon, P. Zink, S. Gopalan, and U.B. Pal: J. Power Sources, 2007, vol. 172 (1), pp. 39-49.

30. A.J. Bard and L.R. Faulkner: Electrochemical Methods: Fundamentals and Applications, 2nd ed., Wiley, New Jersey, 2001.

31. K.E. Oberg, L.M. Friedman, W.M. Boorstein, and R.A. Rapp: Metall. Trans., 1973, vol. 4 (1), pp. 75-82.

32. S. Yuan, U. Pal, and K.C. Chou: J. Electrochem. Soc., 1994, vol. 141 (2), pp. 467-74.

33. P. Soral, U. Pal, H.R. Larson, and B. Schroeder: Metall. Mater. Trans. B, 1999, vol. 30B, pp. 307-21.

34. K.J. Yoon: Ph.D. Dissertation, Boston University, 2008.

35. C.H.P. Lupis: Chemical Thermodynamics of Materials, Elsevier, Amsterdam, 1983.

36. S. Ozawa, K. Morohoshi, T. Hibiya, and H. Fukuyama: J. Appl. Phys., 2010, vol. 107, p. 014910.

37. A. Roine: HSC Chemistry, 5.11, Outokumpu Research Oy, 2002.

38. M. Filal, C. Petot, M. Mokchah, C. Chateau, and J.L. Carpentier: Solid State Ionics, 1995, vol. 80, pp. 27-35. 